\title{
Arkilähtöinen kotitalousneuvonta ja -kasvatus nuorten siirtymävaiheiden tukena
}

\author{
Sanna Sekki ja Minna Autio
}

\section{TIIVISTELMÄ}

- Nuoruuden siirtymävaiheet ovat pitkittyneet ja monimutkaistuneet. Haavoittuvissa elämäntilanteissa eläville nuorille tuen saaminen ja tuen oikea-aikaisuus ovat keskeisiä siirtymävaiheen onnistumisen kannalta. Nuorten tukeminen on kohdistunut pääasiassa kouluttautumisen ja työllistymisen edistämiseen. Sen sijaan arjen taitojen oppimiseen, kuten itsestä huolehtimiseen ( $\mathrm{mm}$. vaatehuoltoon, hygieniaan) tai raha-asioiden hoitamiseen, ei ole kiinnitetty yhtä paljon huomiota. Tutkimme kotitalousasiantuntijoiden näkemyksiä nuorille suunnatusta kotitalousneuvonnasta, jonka avulla tuetaan haavoittuvassa asemassa olevien nuorten arjen taitoja ja sitä kautta kiinnittymistä yhteiskuntaan. Tutkimusaineisto koostuu kotitalousasiantuntijoiden teemahaastatteluista $(n=11)$. Analysoimme kotitalousasiantuntijoiden näkemyksiä siitä, miten he rakentavat ymmärrystä arjen haasteista kartoittamalla nuorten elämismaailmaa sekä miten he vastaavat nuorten tuen tarpeeseen. Asiantuntijat painottivat yhdessä tekemistä sekä malli- ja vertaisoppimista. He liittivät ryhmätoimintaan kotitalouden opetukselle tyypillisiä sisältöjä, kuten ruoanvalmistusta, kodin puhtaanapitoa ja kuluttamista. Nuorten kanssa työskentely ohjaa asiantuntijoita toiminaan kasvattajina, joten toimintaa voi kutsua arkilähtöiseksi kotitalouskasvatukseksi. Tutkimus rakentaa ymmärrystä siitä, miten arkilähtöinen kotitalouskasvatus tuo käytännöntaitojen opettamisen osaksi nuorten siirtymävaiheiden tukemista. Nuoret tarvitsevat konkreettista, arkeen suuntautuvaa, sosiaalipedagogisesta näkökulmasta suunniteltua tukea muiden tukipalveluiden rinnalle.

Asiasanat: arkilähtöisyys, nuoret, kotitalousneuvonta, taidot, kotitalouskasvatus, sosiaalipedagogiikka 


\section{ABSTRACT \\ EVERYDAY HOUSEHOLD COUNSELLING AND EDUCATION TO SUPPORT YOUNG PEOPLE'S TRANSITION TO ADULTHOOD}

- The transition periods of youth have been prolonged and complicated. Access to support and its timeliness are essential for the success of the transition period for young people living in vulnerable life situations. Support for young people has largely focused on promoting education and employment. However, the same attention has not been paid to the learning of everyday skills, such as self-care (clothing, hygiene, etc.) or financial skills. We are studying household counseling produced by a non-governmental organisation (NGO), which supports the everyday skills of young people in a vulnerable position through group activities and, consequently, their attachment to society. The research data consists of thematic interviews with household experts $(n=11)$. We analyse the views of household experts on how they build an understanding of everyday challenges by mapping out the living world of young people and responding to their need for support. The experts emphasised working together as well as modelling and peer learning. In group activities, they used pedagogical tools and contents typical of household education, such as food production, cleaning and consumption. Working with young people guides experts in their activities more strongly as educators in what can be termed everyday household education. Research builds an understanding of how this type of education teaches practical skills in support of young people's transitions. Young people thus need practical support for their everyday lives through social pedagogy alongside other support services.

Key words: everyday life, young people, household counselling, home economics education, skills, social pedagogy

\section{Johdanto}

Ulttuurinen malli ohjaa nuoria aikuisuuden kynnyksellä oman posuorittaminen, työelämään siirtyminen ja perheen perustaminen (Kojo 2012). Nuorten siirtymävaiheet eivät kuitenkaan ole lineaarisia (Gale \& Parker 2014). Etenkin haavoittuvissa elämäntilanteissa olevilla (Virokannas, Liuski \& Kuronen 2020) nuorilla siirtymävaiheet pitkittyvät ja monimutkaistuvat sekä tuen tarve lisääntyy (Aaltonen, Berg \& Ikäheimo 2015; Aaltonen \& Kivijärvi 2017; Woodman \& Wyn 2018). Nuoruuden siirtymävaiheisiin liittyy erilaisia haasteita niin yhteiskunnan rakenteellis- 
ten tekijöiden kuin yksilön ominaisuuksien ja läheisverkostojen näkökulmasta. Siirtymien onnistumista kuvaavana indikaattorina käytetään usein koulutuksen ja työn ulkopuolella olevien nuorten määrää. Nuorten työttömyyttä ja alhaista koulutustasoa on pidetty vakavana uhkana, koska ne heikentävät mahdollisuuksia työmarkkinoilla pitkällä aikavälillä ja samalla rapauttavat nuoren luottamusta yhteiskuntaan. (Hiilamo 2018, 153.)

Erilaiset hyvinvointiongelmat, kuten toimeentulon vaikeudet tai mielenterveyden ongelmat kasautuvat todennäköisimmin nuorille, joilla ei ole koulutusta (Arnardottir 2020, 71-72). Perhetausta ja kasvuolosuhteet vaikuttavat nuoren yhteiskuntaan kiinnittymiseen, minkä vuoksi osa nuorista tarvitsee erityistä tukea koulutukseen tai työelämään siirtyessään (mt.). Sosiaalisen tuen tarve ja läheisverkostojen merkitys korostuvat aikuisuuden kynnyksellä (Paulsen \& Berg 2016, 128; Xie, Sen \& Foster 2014, 32).

Sosiaalipedagoginen lähestymistapa tarjoaa työvälineitä ymmärtää nuorten kasvamiseen, yhteiskunnan jäseneksi tulemiseen sekä yksilön ja hänen sosiaalisen ympäristönsä suhteiden kehittymiseen liittyviä kysymyksiä (Grunwald \& Thiersch 2009). Tärkeässä osassa on haavoittuvissa elämäntilanteissa elävien nuorten sosiaalisten suhteiden tukeminen ja suhteisiin liittyvien ongelmien ehkäisy (Nivala 2007, 78). Sosiaalipedagogisesti orientoituneessa toiminnassa näihin tukiprosesseihin kietoutuu sosiaalinen ja kasvatuksellinen ulottuvuus (Nivala 2007, 84; Hämäläinen 2012). Nuoren toimijuuden edellytyksiä pyritään vahvistamaan kohtaamalla tukea tarvitseva yksilö subjektina eikä toimenpiteiden kohteena (Nivala \& Ryynänen 2019, 196).

Eija Semin $(2006,67)$ mukaan sosiaalipedagogisen toiminnan perustelut tulevat näkyviksi silloin, kun ihminen ei löydä paikkaansa arkielämän toiminnoissa tai ei saavuta riittävää elämänlaatua ylläpitävää elämänhallintaa. Tätä ihmisen arjen merkitystä korostavaa lähestymistapaa on luonnehdittu arkilähtöiseksi sosiaalipedagogiikaksi, jossa pyrkimyksenä on tukea ihmisiä ratkaisemaan arjen ongelmia sekä saavuttamaan niitä valmiuksia ja taitoja, joita arjessa selviytyminen vaatii (Hämäläinen 2003, 68; Thiersch 1986). Hämäläisen (2003, 68-69) mukaan arkilähtöinen työskentely tarjoaa uusia näkökulmia, mahdollisuuksia ja onnistumisia sekä välineitä omassa arjessa ja laajemminkin yhteiskunnassa toimimiseen.

Nuorten parissa tehtävästä työstä voidaan usein tunnistaa sosiaalipedagogiselle orientaatiolle ominaisia piirteitä, vaikka työtapa ei varsinaisesti kiinnittyisi sosiaalipedagogiseen viitekehykseen (Nivala \& Ryynänen 2017, 75). Tutkimuksissa arki voi olla osa tarkastelunäkökulmaa, kuten 
nuoriso- ja sosiaalityön tutkimuksissa ja selvityksissä (esim. Muukkonen, Nevalainen, Ohisalo \& Turunen 2014; Karjalainen \& Viljanen 2009; Kauppinen 2018), vaikka tutkijat eivät itse määrittelisikään tulokulmaansa arkilähtöiseksi. Arjen taitojen tukemista voi olla esimerkiksi kotitalouskurssin suorittaminen osana nuorisotyötä (Muukkonen ym. 2014, 25) tai ruoanlaittotaitojen oppiminen nuorisotalolla (Kauppinen 2018).

Tutkimme Marttaliiton toteuttamaa kotitalousneuvontaa, joka on kohdennettu haavoittuvassa asemassa oleville nuorille. Määrittelemme kotitalousneuvonnan arkilähtöiseksi työotteeksi. Tutkimme sitä, miten kotitalousneuvonnan keinoin, käytäntöön suuntautuvalla työotteella tuetaan nuorten arjen osaamista sekä kiinnittymistä yhteiskuntaan. Olemme haastatelleet järjestön kotitalousasiantuntijoita, jotka ryhmätoiminnan kautta - yhdessä nuorten kanssa toimien - tukevat nuorten taitojen ja valmiuksien kehittymistä. Westergaard $(2013,99)$ on tuonut esiin, että on tärkeää tutkia myös koulun ulkopuolella nuorten kanssa toimivien ammattilaisten näkemyksiä siitä, mikä neuvontatyössä toimii ja mikä ei, ei siis vain keskittyä nuorten omiin näkemyksiin heille tuotetuista palveluista (esim. Välimäki, Aaltonen \& Kivijärvi 2020). Analysoimme sitä, miten kotitalousasiantuntijat muodostavat ymmärryksen haavoittuvassa asemassa olevien nuorten tuen tarpeesta sekä sitä, millaisia pedagogisia ratkaisuja asiantuntijat toteuttavat nuorten kanssa toimiessaan. Tutkimme siis sitä, mitkä neuvonnan sisällöt ja ohjauksen muodot toimivat (ks. Westergaard 2013) nuorten arkisten taitojen, kuten ruoanlaiton ja vaatehuollon edistämisessä.

\section{Siirtymävaiheen tuki: työ- ja koulutusosaamisesta kohti arjen taitoja}

Nuoren elämänkulussa siirtymävaiheet ovat merkityksellisiä, koska niillä on kauaskantoiset vaikutukset hyvinvointiin ja siihen, millaisia elämänvalintoja nuori myöhemmin tekee (Melandro, Campos, Rodriguez-Bravo \& Resino 2020 , 9). Nuoruuden siirtymävaiheita (transition) voidaan tarkastella ja määritellä eri tavoin. Siirtymät voidaan nähdä yhteiskunnan yksilölle tarjoamina kehityspolkuina (societal trajectory) esimerkiksi koulutussiirtymien yhteydessä tai mikrotasolla päivittäisten käytäntöjen ja toimintaympäristöjen välillä tapahtuvina siirtyminä (Hedegaard \& Fleer 2019, 4-6; Kausholt 2019, 158).

Siirtymävaiheiden haasteellisuus on tunnistettu nuorten tukemisen käytännöissä (Fabian \& Dunlop 2002; Aaltonen, Berg, \& Ikäheimo 2015; 
Woodgate, Morakinyo \& Martin 2017; Edwards \& Hedegaard 2019). Merkittävä osa tukitoimista on kohdennettu nuorten työelämätaitojen ja -valmiuksien edistämiseen, koska työllisyyttä pidetään edelleen vahvana mittarina nuorten yhteiskuntakelpoisuudelle (Kiilakoski 2014; Hyvönen \& Valtonen 2014; Woodgate, Morakinyo \& Martin 2017; Välimäki ym. 2020). Nuorille suunnattu työpajatoiminta ja nuorten ohjaamopalvelut pyrkivätkin integroimaan nuoren yhteiskuntaan paljolti työllistymisen näkökulmasta (Komonen 2008, 171).

Hiilamo ym. (2017, 29-30) ovat tuoneet esiin, että kaikkein haavoittuvimmissa tilanteissa olevat nuoret tarvitsevat näiden aktivointitoimenpiteiden rinnalle uusia ja vaihtoehtoisia polkuja työelämään tai yhteiskunnassa aktivoitumiseen. Koulutus- ja työelämävalmiuksien rinnalla itsenäistä arkea elävä nuori joutuu ottamaan vastuuta paitsi itsestään, myös erilaisista kodin toiminnoista, raha-asioiden hoitamisesta sekä viranomaisten kanssa asioimisesta (Allen \& Williams 2012, 327-330; Korvela \& Nordlund 2016, 193-195). Myös yhteiskunnan toimintoja mukailevalla arkirytmillä on tärkeä merkitys (Korvela 2014, 321-322) nuoren koulutukseen osallistumiselle tai työssä käymiselle. Arjen moninaisista toiminnoista suoriutuminen sekä koulutuksessa ja työssä pärjääminen sisältävät oletuksen nuoren aktiivisesta toimijuudesta (Mary 2012, 292; Juvonen 2015, 31).

Arjen sujuvuuden ja jatkuvuuden turvaamiseksi nuoret tarvitsevat konkreettisia neuvoja ja ohjeita ruoanvalmistukseen, pyykinpesuun, arjen aikatauluttamiseen sekä oman talouden suunnitteluun (Häggman-Laitila, Salokekkilä \& Karki 2018, 139; Paulsen \& Berg 2016, 128; Liabo, McKenna, Ingold \& Roberts 2016, 188-189; Autio, Lähteenmaa, Holmberg \& Kujala 2016, 105; Kortesalmi \& Autio 2019, 5). Arjen toimintojen sujuminen vapauttaisi voimavaroja elämän muille osa-alueille, ja samalla arjen käytäntöjen sujuminen vahvistaisi nuoren itsenäisyyttä (Paulsen \& Berg 2016, 128). Konkreettisten arjen käytäntöjen tukemisen ja kehittämisen lisäksi tarvitaan tukea, jonka avulla nuorta voidaan auttaa ymmärtämään elämäntilannettaan ja tiedostamaan erilaisia mahdollisuuksia omassa arjessaan nykyisen tilanteen kohentamiseksi (Ranne 2007, 306; Hämäläinen 2012 , 12). Nuorten näkemyksiä arjen sujumisen merkityksestä ei kuitenkaan ole juuri huomioitu syrjäytymisen ehkäisyyn liittyvien toimenpiteiden suunnittelussa (Kestilä, Kauppinen \& Karvonen 2016, 118). Välimäki ym. $(2020,25)$ ovat tuoneet esiin, että esimerkiksi ohjaamotoiminnassa nuoria tuetaan myös arkeen ja vapaa-ajan toimintoihin liittyvissä kysymyksissä, ei vain koulutukseen ja työllistymiseen liittyvissä haasteissa. 


\section{Kotitalouslähtöinen ryhmätoiminta nuorten arjen toimintoja tukemassa}

Hans Thiersch (1986) on kehittänyt arkilähtöistä tai arkisuuntautunutta lähestymistapaa elämismaailmalähtöisessä sosiaalipedagogiikassa, jossa tavoitteena on ihmisten tukeminen niin, että he kykenevät ratkaisemaan arjen ongelmia sekä saavuttamaan valmiuksia ja taitoja, joita arjessa selviäminen vaatii (Hämäläinen 2003, 70; Semi 2006, 118-119). Arki itsessään on moniulotteinen käsite ja se ymmärretään usein rutiineina, toistoina ja käytänteinä (Featherstone 1992, 55; Felski 1999, 20-22). Thierschille arki on kirjava kokonaisuus erilaisia käytännöllisiä asioita, tehtäviä, rooleja ja rutiineja (Hämäläinen 2003, 68). Arkilähtöinen sosiaalipedagogiikka tähtääkin käytännöllisten asioiden ymmärtämiseen, hoitamiseen ja edistämiseen. Tavoitteena on, että ihminen onnistuu luomaan sujuvan arjen (Hämäläinen 2003, 68). Arjessa säännöllisesti toistuvat toiminnot ja arkirytmi muodostavat toimivan arjen perusrakenteen ja tuottavat yksilölle hyvinvointia (Felski 1999; Korvela 2014). Lefebvren $(2002,21)$ mukaan arkiset toiminnot rakentuvat jokapäiväisten asioiden ympärille (kuten ravinto, vaatetus, sisustus ja koti). Kotitalouden arki ei rajoitu näin kodin seinien sisäpuolelle, vaan se on vuorovaikutuksessa lähiyhteisöjen ja yhteiskunnallisten rakenteiden kanssa (Salmi 2004).

Raija Hovi-Pulsa (2011, 85-98) on soveltanut sosiaalipedagogista lähtökohtaa kehittäessään arkilähtöistä perhetyötä. Hän tulkitsi arkilähtöisyyden konkreettisena arjen tukemisena ja auttamisena eli päivittäisten arjen asioiden sujumisen varmistamisena. Arkilähtöisessä työtavassa pyritään aluksi vuorovaikutuksessa asiakkaan kanssa löytämään yhteinen tulkintahorisontti arjen haasteista. Näiden tunnistettujen haasteiden parissa sitten työskennellään asiakkaan kanssa huomioiden elämänhistoria ja nykytilanne sekä lähiympäristö ja sosiaaliset suhteet. Arkilähtöistä työskentelyä ohjaa pedagogisen suhteen lisäksi ammatillinen ymmärrys asiakkaan tilanteesta (Hovi-Pulsa 2011, 96).

Tarkastelemme kotitalousneuvontaa sosiaalipedagogisesta näkökulmasta, koska kotitalousneuvojat työskentelevät ihmisten arkipäivän ongelmien parissa (Heinonen 1998, 376). Kotitalousneuvonnan tarkoituksena on ollut - ja on edelleen - ohjata ja tukea ihmisiä sujuvoittamaan arkisia toimintojaan (Ollila 1993, 63). Toiminnan kantavana ajatuksena on tukea yksilöitä ja perheitä sekä rohkaista heitä vastuun ottamiseen tarjoamalla ohjeita, tietoa ja erilaisia vaihtoehtoja (Westermarck 2014). Neuvonnalla on pyritty muuttamaan arkisia tapoja ja tottumuksia (Ollila 1993, 63). Ko- 
titalousneuvonnassa tuetaan toimintoja, jotka ovat ihmisten arjessa konkreettisesti läsnä, eli neuvonnan sisällöt muuttuvat toimintaympäristön ja yhteiskunnan muuttuessa, esimerkiksi tekniikan kehityksen vaikuttaessa kotitöihin. Marttojen neuvonnan aiheet ovat liittyneet esimerkiksi puutarhanhoitoon, taloustaitoihin, kodinhoitoon, ruokaan ja ravitsemukseen (Ollila 1993; Jalovaara 2019).

Kotitalousneuvonnan yhdeksi toimintamuodoksi on viime aikoina vakiintunut ryhmätoiminta, jossa yksilön tukeminen tapahtuu ryhmäoppimisen kautta. Allenin ja Williamsin $(2012,329)$ mukaan ryhmätoiminta on tapa rakentaa nuorten osallisuutta suhteessa omaan toimintaympäristöön, koska toiminnan kautta voidaan tarjota keskinäistä tukea, kokemusmahdollisuuksia, vuoropuhelua ja ongelmanratkaisutaitoja. Myös Nivala (2007, 30) muistuttaa, että osallisuudessa korostuvat yhteistoiminnallisuus, vuorovaikutus sekä yksilön kokemus osallisuudesta. Ryhmätoiminnan avulla voidaan opetella yhdessä kokemuksellisesti erilaisia arjen taitoja, jotka valmistavat itsenäiseen arjessa selviytymiseen. Toimivan ja sujuvan arjen kannalta tarvitaan valmiuksia omasta hyvinvoinnista, läheissuhteista ja erilaisista kodin toiminnoista huolehtimiseen ( $\mathrm{mm}$. asuminen, vaatehuolto, kodin puhtaanapito, ruokahuolto). Sen lisäksi tarvitaan työnhakuun, asioiden hoitamiseen ja laajemmin yhteiskunnassa toimimiseen liittyviä taitoja (Nivala 2007). Ryhmätoiminnalla rakennetaan perustaa näiden taitojen käyttöönotolle arjessa myös vahvistamalla nuorten elämänhallintaa ja uskoa omiin kykyihin. Ryhmässä tapahtuvaa työskentelyä on käytetty nuorten tukemisessa, ja ryhmälähtöisyys tarjoaa nuorelle aikuiselle sosiaalisia mahdollisuuksia tutustua samassa elämäntilanteessa oleviin (Välimäki ym. 2020, 33). Ryhmätoiminta kiinnittyy myös nuorten kasvun ja kasvatuksen kysymyksiin (Nivala 2007, 30). Välimäki ym. (2020, 28) ovat kuitenkin tuoneet esiin, että haavoittuvassa asemassa olevien nuorten kanssa toimittaessa on kiinnitettävä huomio siihen, että kaikilla nuorilla ei ole valmiuksia osallistua ryhmätoimintaan esimerkiksi mielenterveysongelmien tai rankkojen koulukiusaamiskokemusten vuoksi.

\section{Tutkimuskohde, aineiston hankinta ja analyysi}

Tutkimme arkilähtöistä neuvontatyötä tarkastelemalla kotitalousasiantuntijoiden näkemyksiä siitä, miten he kokevat tukevansa haavoittuvassa asemassa olevien nuorten arjen taitoja. Ryhmätoiminta on neuvonnan ja ohjauksen keskeinen oppimisen menetelmä. Artikkelissa kysymme, i) miten asiantuntijat rakentavat ymmärrystä arjen haasteista yhdessä nuor- 
ten kanssa ja ii) millaisia pedagogisia ja sisällöllisiä ratkaisuja ryhmätoiminnassa käytetään nuorten kanssa toimittaessa. Asiantuntijat työskentelevät tai ovat työskennelleet Marttaliiton organisoimassa Ihan jees arki -hankkeessa (2018-2020), jonka tavoitteena on tukea 15-29-vuotiaiden nuorten arjen taitoja kotitalousneuvonnan, erityisesti ryhmätoiminnan keinoin. Hankkeen kohderyhmänä ovat työn ja koulutuksen ulkopuolelle jääneet nuoret. Yhteistyökumppanit ohjaavat yksittäisiä nuoria ja ryhmiä hankkeen työskentelyyn. Hanketyöskentely on osa nuorten kuntoutusprosessia tai muuta palvelukokonaisuutta. Toimintaan osallistuminen perustuu nuorten vapaaehtoisuuteen. Yhteistyökumppanin edustaja osallistuu useimmiten ryhmätoimintaan kotitalousasiantuntijan rinnalla. Hankkeeseen on osallistunut yli 500 nuorta, joista miehiä on hieman enemmän kuin naisia.

Ryhmätoiminta jäsentyy kuuden kerran neuvontakokonaisuudeksi, jossa jokaista tapaamiskertaa varten on valittu nuorten arjen hallintaa ja hyvinvointia tukeva teema. Teemoja ovat edullinen ja terveellinen ruoka, ravitsemus, kodin puhtaanapito, vaatehuolto ja raha-asioiden hoitaminen. Hankkeessa on mahdollisuus myös nuorten kotona tapahtuvaan yksilöohjaukseen. Konkreettisten arjen taitojen oppimisen yhteydessä nuorilla on mahdollisuus pohtia omaa elämäänsä kotitalousasiantuntijoiden kanssa. Asiantuntijoilla on pedagogista osaamista työskentelystä erityisryhmien kanssa. Verrattuna koulutus- ja työelämävalmiuksia rakentaviin projekteihin, käsillä olevassa hankkeessa painottuu nuorten itsenäisen arjen tukeminen sekä arjessa selviytyminen (vrt. Hiilamo ym. 2017), mikä rakentaa samalla valmiuksia opinto- ja työpoluille (ks. Sekki \& Autio 2020).

Hankkeen kohderyhmänä olevien nuorten elämä on kapeutunut kotiin ja he ovat "pudonneet" palveluiden ulkopuolelle. Nuorilla on sosiaalisia, emotionaalisia tai taloudellisia ongelmia, jotka heikentävät nuorten elämänhallintaa ja siten mahdollisuuksia kiinnittyä yhteiskuntaan (myös Pekkarinen 2015; Aaltonen, Berg, Ikäheimo 2015). Virokannas, Liuski ja Kuronen $(2020,19)$ ovat tuoneet esiin, että tutkimuksessa ei tulisi määritellä ihmis- ja asiakasryhmiä haavoittuviksi, vaan tulisi puhua haavoittavista elämäntilanteista sekä niitä tuottavista rakenteista. Hyvinvointipalvelut voivat myös ylläpitää haavoittuvuutta (Virokannas ym. 2020, 19). On mahdollista, että hyvää tarkoittava nuorten auttaminen voi nuorten kokemuksena olla kielteistä ja tuottaa siten haavoittuvuutta. Esimerkiksi kotitalousneuvonta on ruokapainotteista, mikä ei lähtökohtaisesti sovellu kaikille nuorille, sillä osa nuorista voi kärsiä syömishäiriöistä tai heillä ei 
ole kokemuksia "yhdessä syömisestä", jolloin he tarvitsisivat toisenlaista tukea ja ohjausta (Sekki \& Autio 2020).

Tutkimusaineisto koostuu kotitalousneuvontaa hankkeessa antavien kotitalousasiantuntijoiden (myöhemmin asiantuntija) teemahaastatteluista $(n=11)$, jotka on toteutettu hankkeeseen osallistuneissa alueellisissa Marttapiireissä. Haastatteluihin osallistuivat kaikki hankkeessa syksyllä 2019 työskennelleet asiantuntijat $(n=7)$. Tämän lisäksi haastatteluihin pyydettiin hanketyössä aiemmin mukana olleita työntekijöitä $(n=4)$. Kaikki työntekijät ovat naisia, mikä kertoo siitä, että kotitalouden toimintoihin liittyvä koulutus ja osaaminen on sukupuolittunutta (Heinonen 2012). Haastateltavilla on useamman vuoden kokemus vastaavanlaisesta hanketyöskentelystä ja taustaltaan he ovat pääosin kotitalouden ammattilaisia. Haastatteluiden kesto vaihteli 63-115 minuutin välillä ja tallenteita kertyi 14 tuntia 45 minuuttia. Litteroinnin yhteydessä haastattelut anonymisoitiin ja tutkittaville annettiin pseudonyymit eli peitenimet (Aineistonhallinnan käsikirja 2019).

Haastatteluiden tavoitteena oli tunnistaa asiantuntijoiden toimintatapoja ja näkemyksiä nuorten arkilähtöisestä tukemisesta. Haastattelun teemoja olivat nuorten arki ja avuntarve, ryhmätoiminnan toteuttaminen ja sisällöt sekä kotitalousasiantuntijoiden työskentelytavat ja menetelmät. Haastattelututkimuksen avulla pyritään ymmärtämään sosiaalista todellisuutta painottamalla tutkittavien kokemusmaailmaa ja heidän toiminnalleen antamia merkityksiä (Honkatukia 2018, 150). Tämä tarkoittaa, että aineistosta voi tulkita sitä, miten asiantuntijat kokevat ohjaavansa ja tukevansa nuoria, mutta ei sitä, mitä ja miten nuoret kokevat oppivansa taitoja hankkeen aikana.

Aineiston hankinnassa ja käsittelyssä on toimittu keskeiset eettiset periaatteet huomioiden (Aineistonhallinnan käsikirja 2019). Tutkimusluvat hankittiin Marttaliitolta sekä haastattelutilanteessa henkilökohtaisesti haastatteluun osallistuneilta asiantuntijoilta. Haastateltavien kanssa käytiin läpi tutkimuksen tarkoitus sekä aineiston säilytys, käsittely ja käyttö. Haastattelut perustuivat vapaaehtoisuuteen ja haastateltaville annettiin mahdollisuus vetäytyä tutkimuksesta (Fontana \& Frey 2003, 88-89). Olemme kuvanneet tutkimuskohdetta, aineiston hankintaa ja eettisiä ratkaisuja aiemmassa artikkelissa (Sekki \& Autio 2020).

Haastattelujen analysointi pohjaa aineistolähtöiseen sisällönanalyysiin (Hsieh \& Shannon 2005). Vaikka analyysi ei rakennu valmiiden teemojen ympärille, on aiempi kirjallisuus ohjannut keskeisten teemojen tunnis- 
tamista ja nimeämistä (Salo 2015, 182). Kauppisen $(2018,130-131)$ tutkimuksessa, joka kohdistui nuorisotaloilla tapahtuvaan ruokakasvatukseen, ei tunnistettu vakiintuneita menetelmiä tai toimintatapoja nuorten ohjaamisessa. Näin analyysi kohdistui aluksi siihen, miten asiantuntijat kuvasivat ja näkivät nuorten tuen tarpeen sekä miten he reflektoivat työskentelyn alkuvaiheeseen liittyviä vuorovaikutustilanteita nuorten kanssa. Sen jälkeen kiinnitimme huomion asiantuntijoiden käyttämiin toimintatapoihin ja menetelmiin.

Analyysi eteni aineiston luennan, pelkistämisen ja ryhmittelyn kautta päätyen kolmeen teemaan (Tuomi \& Sarajärvi 2009, 109-113). Ensimmäinen teema on nuorten elämismaailman kartoittaminen (Grunwald \& Thiersch 2009). Tämä tarkoittaa, että analysoimme asiantuntijoiden kuvauksia siitä, miten he muodostivat ymmärryksen nuorten taidoista ja elämäntilanteista (vrt. yhteinen tulkintahorisontti, Hovi-Pulsa 2011, 85-98). Tämän jälkeen tarkastelimme tuen tarpeeseen vastaamista eli sitä, miten asiantuntijat puhuivat omista menettelytavoistaan ja käytännöistään sekä työskentelyn sisällöistä ryhmätoiminnassa. Asiantuntijoiden kuvaamat menettelytavat ja käytännöt muodostivat toisen teeman eli pedagogiset ratkaisut, joiden avulla asiantuntijat pyrkivät tukemaan nuorten arjen taitojen kehittymistä. Asiantuntijoiden puheessa pedagogisiin ratkaisuihin kiinnittyivät työskentelyn sisällöt, joita tarkastelemme kolmannen teeman alla. Se on kotitalouspainotteiset materiaalit ja sisällöt. Olemme valinneet tulosten yhteyteen runsaimmin aineistositaatteja Helenalta, koska hän sanoitti ja kiteytti haastateltavien yhteisesti jakamia käsityksiä.

\section{Nuorten elämismaailman ymmärtäminen vaatii vuorovaikutusyhteyden rakentamista}

Asiatuntijat näkevät, että nuorten tuen tarpeen tunnistaminen ohjaa kotitalousneuvonnan toteutusta ja sisältöjen rakentumista. Myös nuoria kotitalousneuvonnan piiriin ohjaavien yhteistyökumppanien toiveet ja näkemykset auttavat tuen tarpeen tunnistamista. Toiminta käynnistyy ryhmätapaamisella, jossa nuorten kanssa keskustellaan yksityiskohtaisemmin tulevasta työskentelyjaksosta. Käytännön työskentelyssä nuorten elämismaailman ymmärtämiseksi asiantuntijat korostivat ensinnäkin ammatillisten havaintojen tekemistä nuorten kanssa toimiessa sekä nuoriin tutustumista työskentelyn edetessä.

Asiantuntijoiden havaintojen mukaan ryhmätoimintaan osallistuvat nuoret ovat erilaisissa siirtymävaiheissa kohti opiskelupaikkaa tai työelä- 
mää, mikä heijastuu avun tarpeeseen sekä kykyyn ottaa vastaan tukea ja toimia ryhmässä. Myös yksilöohjauksesta ryhmäohjaukseen siirtyminen näyttäisi olevan iso askel nuorelle. Kävi ilmi, että päivittäinen kotoa lähteminen ja ryhmätoiminnan käytäntöjen omaksuminen vie aikaa. Asiantuntijat toivat esiin, että toiminnalliseen ryhmätyöskentelyyn osallistuminen ei olekaan heti realistinen tavoite (myös Välimäki ym. 2020), vaan paikalle tuleminen ja ryhmässä mukana oleminen muodostuvat työskentelyn ensisijaisiksi tavoitteiksi. Sen sijaan pidempään työpajoissa tai yhteistyökumppanin toiminnassa mukana olleet nuoret ovat tuelle vastaanottavaisempia ja tarvitsevat vähemmän henkilökohtaista ohjaamista.

Asiantuntijat kohtasivat myös nuorten siirtymävaiheiden moninaisuuden. Hankkeessa kotitalousneuvonnan piiriin ohjatut nuoret olivat hyvin erilaisissa elämäntilanteissa: nuori saattoi vapautua vankilasta, itsenäistyä asumisyksiköstä tai muuttaa vanhempien tai huoltajan luota ensimmäiseen omaan kotiin. Nuorten käsitykset omasta kodista ja siihen liittyvistä toiminnoista vaihtelivat sen mukaan, millaisia kokemuksia heillä on kodista. Myös perheissä opitut arjen tiedot ja taidot vaihtelivat. Helena kertoo, miten erilaisista taustoista nuoret ryhmätoimintaan tulevat:

Mutta ruuan valmistuksen yhteydessä on noussut esiin se että, yllättäen nuori saattaa sanoa että "mä en ole koskaan saanut kotona tehdä tätä". Tai on ollut semmoisiakin nuoria hyvistä perheistä, joissa yllättäen on tullut se että "en ole saanut kokkailla koska meillä on edustuskeittiö". (Haastattelu 9, Helena.)

Haastatteluissa tuli esille, että käytännönläheinen ja toiminnallinen työskentely tuki nuoriin tutustumista. Tämä yhdessä tapahtuva toiminta, kuten ruoanvalmistus, rakentaa asiantuntijoille näkemystä siitä, millaista arjen osaamista ja millaisia valmiuksia nuorilla on ryhmässä toimimiseen. Asiantuntijat kertoivat, että he tarvitsevat myös yksilöidympää tietoa nuoren arjen sujumisesta, jotta työskentely kiinnittyisi taitoja vahvistavasti nuoren arkeen. Nuori nähtiin oman arkensa asiantuntijana.

Nuorten elämismaailman ymmärtämisen kannalta asiantuntijat toivat toiseksi esille vuorovaikutusyhteyden rakentamisen merkityksen. Luottamuksellinen ilmapiiri ja vuorovaikutussuhteen aktiivinen rakentaminen syvensivät nuorten elämäntilanteen ymmärtämistä. Annikki kertoo, miten työskentely käynnistyi nuorten kanssa: 
Semmoinen yksilöllinen haastattelu ja kartoittaminen ja semmoinen keskustelu ja vuorovaikutus on tärkee et päästään ylipäätänsä näkemään et mikä se tilanne on ja mihin nuori tarvii apua. Ja sitten tavallaan et se vaatii sitä luottamusta ja sellaista että se nuori tulee kohdatuksi siten että hän ylipäätänsä haluaa jollekin asiantuntijalle jakaa. (Haastattelu 3, Annikki.)

Vaikka käytännönläheinen toiminta ja yhdessä tekeminen tukivat nuorta koskevan tiedon kartoittamista, nuorten tavoittaminen oli ajoittain haastavaa ja siihen tuli resursoida aikaa. Vuorovaikutuksen toteutumista ei pidä ottaa itsestäänselvyytenä, vaan sen rakentamiseen tulee panostaa. Nuorilla oli myös vaikeuksia sanoittaa omia tarpeitaan ja toiveitaan. Arjen sujumiseen liittyvät ongelmat jäivät helposti muiden elämänalueiden, kuten uupumisen tai muiden ongelmien varjoon. Nuorten kanssa työskentelyssä näyttää olevan tärkeää tunnistaa vaihe, jolloin nuori on valmis vuorovaikutukseen ja mahdollisesti valmis tuomaan esille omia toiveitaan tai tarpeitaan. Sirkka kuvaa, miten yhdessä tapahtuva ruoanvalmistus voi luoda vuorovaikutustilanteita ja keskustelunavauksia asiantuntijoiden ja nuorten välille:

Saattaa olla, että ruoka on siinä, tai se jotain mitä tehdään niin se on kimmoke siihen että, aletaan kertoo omasta perheestä tai mitä kaverit tekee joko ruokaan liittyen tai sitten ihan, täysin muita asioita. Sitten on niitä jotka, hädin tuskin vastaa jos heiltä kysyy jonkun suoran kysymyksen. Mutta sitten, no, tässä oli taas että kun on kuus kertaa niin sitten pikkuhiljaa pehmittää heitä niin, se saattaa olla et siinä ryhmätoiminnassakin et jos on vasta tullut ryhmätoimintaan mukaan niin sitten on vaan niin lukossa että ei niin $k u$, heiltä ei voi niin hirveesti siinä alussa vaatia. (Haastattelu 1, Sirkka.)

Sitaatissa ilmenee, miten työskentely etenee, vaikka nuoret eivät heti lähtisi mukaan vuorovaikutustilanteisiin. Usein kärsivällisyys nuoren kohtaamisessa tuottaa tulosta ja nuori voi aktivoitua työskentelyjakson loppua kohden. Puheenvuorosta ilmenee myös asiantuntijan vahva ote nuorista, kun hän käyttää kielikuvia "pehmittää" ja "vaatii".

Nuorten elämismaailman ymmärtämisessä auttaa asiantuntijoiden mukaan nuorten ottaminen mukaan työskentelyn suunnitteluun. Samalla se on keino saada heitä aktivoitumaan ja kiinnostumaan taitojen oppimi- 
sesta. Jos nuori ei koe ryhmäkerran sisältöjä merkityksellisinä, toiminnot eivät välttämättä kiinnity arkeen. Jotta toiveet saatiin esiin, ryhmätoiminnan suunnittelu tehtiin nuorille mahdollisimman helposti lähestyttäväksi. Ruokailun yhteydessä käytiin usein alustavaa keskustelua seuraavasta kerrasta, jolloin teeman ja ruokalajien pohtiminen oli luonteva osa ruokailutilannetta. Nuorten oli mahdollista ilmaista toiveitaan myös kirjallisesti. Nuorten esittämät toiveet kapeutuivat usein tiettyjen ruokalajien ympärille. Kenties nuoret ajattelivat, että heidän oletetaan kertovat ruoasta, koska hanketyöskentely painottui sen ympärille. Kerttu kertoo antavansa nuorille mahdollisuuden toiveiden esittämiseen anonyymisti ja joustavasti työskentelyn lomassa. Hänen ryhmissään on kokeiltu myös suoraan toiveiden kysymistä nuorilta sekä äänestämistä.

Oli niitä post-it-lappuja tai johonkin niitä (toiveita) kirjoteltiin. Ja sitten ihan suoraan, yritin kysellä... et just niitä ruokalajeja ehkä jonkun verran sitten ihan tuli ja toki jos käytiin jossain liikkumassa niin sen mä nyt ehdottomasti halusin et se ei oo mikään että minä päätän että nyt mennään kävelylle vaan sitten, joittenkin kaa käytiin ainakin pelaa sulkista niin sit ihan äänestettiin siitä, et mitä tehdään. Mutta siis yllättävän vaikeethan sieltä oli monesta nyhtää yhtään mitään. Mutta jonkun verran semmoista asennetta, että ihan sama. (Haastattelu 11, Kerttu.)

Haastatteluissa nousi esiin, että nuorten arkirytmi on erilainen kuin aikuisyhteiskunnan, mikä näkyi työskentelyn suunnittelun ja toteutuksen rytmityksessä. Neuvontaa tuli sopeuttaa nuorten aikatauluihin. Myös nuorten ikä ja elämäntilanne haastoivat ohjauksen suunnittelua - nuorille leimallinen "ihan sama" -näkemys kertoo heidän ajattelustaan. Nuorille tuotti vaikeuksia tehdä kodin välttämättömiä toimintoja, kuten kodin puhtaanapitoa ja vaatehuoltoa. Yhteiskunnan normitetun arkirytmin ylläpito heijastui myös nuorten terveydestä ja hyvinvoinnista huolehtimiseen, kuten ruokailurytmiin. Asiantuntijoille tuotti vaikeuksia sovittaa oma rytminsä nuorten rytmiin. Ellin puheenvuorosta ilmenee toimijoiden välinen näkemysero:

Vähän sellainen saamattomuus, tietyllä tavalla. Arki, rytmi on hukassa, se on aika yleistä. Mutta sitten heiltä puuttuu kuitenkin semmoinen, että he eivät oikein saa aikaan, ja energiat menevät vähän johonkin muualle. (Haastattelu 6, Elli.) 
Grunwaldin ja Thierschin $(2009,134)$ tutkimuksessa ilmeni, että koko perheen arkirytmi voi olla "hukassa", jos vanhempien elämää haastavat sairaudet ja huono-osaisuus. Näin ongelman asemointi vain nuorten ongelmaksi ei huomioi mahdollisia muita elämänkulkuun liittyviä tekijöitä. Asiantuntijat näkevätkin, että heille on helpompaa pyrkiä ratkaisemaan yksittäisiä taitoon liittyviä haasteita kuin nuorten elämäntapaan liittyviä asioita, kuten nukkumisrytmiä tai riittävää ravintoa. Asiantuntijat toivat kuitenkin esiin nuorten elämäntilanteeseen liittyviä ongelmia, kuten mielenterveysongelmat, toimeentulon vaikeudet tai haasteet sosiaalisessa kanssakäymisessä, jotka tekevät ymmärrettäväksi nuorten arjen ongelmallisuuden. Työskentelyn lomassa asiantuntijat pyrkivät huomioimaan nuorten henkilökohtaisia ominaisuuksia ja tarpeita. Ryhmätoiminnassa nuoria myös heräteltiin pohtimaan elämänsä muutostarvetta (ks. myös Hämäläinen 2003, 69) kiinnittämällä nuorten huomiota arjen eri toimintoihin ja niiden merkitykseen kokonaishyvinvoinnin kannalta.

\section{Pedagogisilla ratkaisuilla kohti taitojen kehittymistä}

Kun käytännön työskentelyn kautta oli löydetty tarttumapintoja nuorten arkeen, asiantuntijat kokivat, että nuorten arjen tukeminen helpottui. Asiantuntijat painottivat työskentelyssä menettelytapoja, joiden avulla he pyrkivät vahvistamaan nuorten toimintatapoja, käytäntöjä ja osaamista siten, että muutto omaan kotiin sekä siirtyminen työharjoitteluun, koulutukseen ja työelämään mahdollistuisi.

Asiantuntijat ymmärtävät nuoret toimijoiksi, joilla arjen taidot tuntuvat olevan "hukassa". Nuoria haluttiin auttaa ja opastaa huolehtimaan omasta hyvinvoinnistaan ja kodistaan - ja siten tulevaisuudestaan. Näin konkreettisen neuvontatyön lisäksi asiantuntijat näkivät itsensä kasvattajan roolissa. Helena pohtii kasvattajan roolia ja tulkitsee arjen taitojen konkreettisen opettelun myös nuoren vahvistamisena ja kannatteluna, etenkin nuoruuden siirtymävaiheessa:

Me vaan ikään kun vahvistetaan ja kannatellaan, ja tuupataan taas eteenpäin. Mutta niinhän se on ihan kenen tahansa kasvattajan rooli. Sitä pitää vaan antaa, että toivottavasti ne siivet kantaa. (Haastattelu 9, Helena.)

Kasvatukselliset tavoitteet ovat osa ryhmätoiminnan pedagogisia ratkaisuja. Asiantuntijoiden mukaan ryhmätoiminnassa painottuu yhdessä 
tekeminen eli arjen käytäntöjä harjoitellaan vuorovaikutuksessa muiden kanssa. Ryhmätoiminnassa yhdessä tekeminen muodostaa ajallisesti merkittävimmän osan ryhmäkertojen toiminasta. Työskentely käynnistyy yhteisellä osuudella, jonka avulla orientoidutaan yhteiseen tekemiseen. Ryhmäkerran alussa asiantuntijat kartoittavat nuorten tuntemuksia yhteisen toiminnan onnistumiseksi, koska väsymys tai muiden ongelmien aktualisoituminen vaikuttavat nuorten osallistumiseen. Asiantuntijat käyttävät esimerkiksi tunnekortteja apuna nuorten "päivän fiiliksen" selvittämisessä (myös Campbell \& Brigman 2005). Yhdessä tekemiseen siirrytään melko nopeasti. Sirkka kuvaa, miten käytännön ruoanvalmistus antaa mahdollisuuden erilaisten asioiden käsittelyyn, koska nuoret ovat keittiöllä vastaanottavaisempia kuin teoriaosuuden aikana.

Ei ole niin kuin, semmoista pitkää teoreettista osuutta. Ja sitten kyselen tietenkin paljon ja näin. Sit siirrytään keittiöön, siellä käydään ruokaohjeet läpi ja siinä sitten, yleensä ihmiset viimeistään alkaa heräillä. Ja silleen et tuntuu että, jäät karisee. Välillä kaikki tulee sinne valmistamaan ruokaa. Sit on ollut niitä että, ohjaaja on tullut sanomaan että tää tyyppi haluaisi tulla mut hän ei pysty. Et sitten siellä jokainen tekee sen verran kun pystyy. Ja sitte meillä on se ruoan valmistus ja siinä tietenkin mä yritän kaiken mahdollisen mitä mä haluun kertoo heille, niin kertoo siellä keittiössä. Siinä on paljon helpompi saada kontakti. Ja sitten jaetaan ryhmät, valmistetaan ruokaa. Syödään yhdessä. Sitten vielä siistitään ja syödään jälkkäriä ja käydään vielä sellainen reflektiokierros. (Haastattelu 1, Sirkka.)

Puheenvuorosta ilmenee toiminnan monitahoisuus, koska nuorten lukumäärä ja toimintakyky vaihtelevat tapaamiskertojen välillä. Yhdessä tekemistä pyritään rakentamaan joustavasti nuorten tilanteita mukaillen, osallistumispakkoa ei ole ja jokainen voi osallistua haluamallaan tavalla.

Asiantuntijat painottavat vertaisoppimista yhteisessä teoriaosuudessa sekä käytännön tekemisessä. Arkeen liittyvät työskentelyn sisällöt antavat mahdollisuuden hyödyntää nuorten omista kokemuksista ja elämäntilanteista kumpuavaa osaamista, jota he yhdessä voivat jakaa. Kun vertaisoppimiseen osallistuu samankaltaisiin sosiaalisiin ryhmiin kuuluvia ihmisiä, yhdessä toimiessaan he auttavat toisiaan ja itseään oppimaan (Topping 2005, 631). Varsinkin oman talouden suunnitteluun liittyvät teemat tarjoavat mahdollisuuksia vertaisoppimiseen, koska rahankäyttö ja oman 
talouden hallinta ovat asiantuntijoiden näkemyksen mukaan kaikkien nuorten jakamia huolenaiheita. Helena kuvaa vertaisoppimisen prosessia ryhmätoiminnassa:

Vertaisoppiminen korostuu siinä, että kun yksi uskaltaa sanoo niin toinenkin lähtee siihen mukaan, ja se on ihan eri juttu kun toinen nuori sanoo että mulla menee vuokraan näin paljon, niin sit toinen että no miks sulla menee noin paljon kun mulla meneekin tän verran. Ja sit verrataan et missä päin asutaan ja, et mitkä vaikuttaa kaikkeen. Sit osaa olla kärppänä nekin jotka on vasta etsimässä omaa vuokrakämppää, että mihin kiinnittää huomiota. (Haastattelu 9, Helena.)

Helenan mukaan keskeisenä edellytyksenä on, että nuori uskaltaa tuoda omia kokemuksiaan yhteiseen keskusteluun. Asiantuntijalla on vastuu vuorovaikutteisen ja luottamuksellisen ilmapiirin rakentamisesta. Yhteisessä keskustelussa asiasta muodostuu laajempi ymmärrys ja nuorille voidaan tuottaa uutta tietoa arkisen toiminnan ja päätöksenteon tueksi. Vertaisoppiminen tulee näkyväksi myös ruoanvalmistuksen yhteydessä, kun kokemusta hankkineet nuoret voivat toimia työskentelyn eri vaiheissa muille tukena sekä ohjata työskentelyä (Kauppinen 2018, 140). Kauppisen $(2018,125,138)$ tutkimuksessa, jossa tarkasteltiin nuorisotalolla tapahtuvaa ruoanvalmistusta, painottuivat ystävien ja vertaisten merkitys sekä yhdessä oppiminen. Yhdessä työskentely tarjoaakin mahdollisuuden vertaistuen saamiseen, kun nuoret huomaavat, että eivät ole yksin ongelmiensa kanssa. Vertaisoppimisen rinnalla myös mallioppiminen on osa yhdessä tekemistä. Helena liittää mallioppimisen ruoanvalmistukseen liittyvien työvaiheiden ohjaamiseen.

Vanhan ajan mallioppiminen, et tehdään yhdessä. Sit vaivihkaa mä siirrynkin seuraavaan pisteeseen et hei tehdään yhdessä. Mä ihan tällä keinolla. (Haastattelu 9, Helena.)

Työskentelyn aikana hänellä on tapana kiertää ryhmissä ohjaamassa nuoria konkreettisesti eri työvaiheissa. Mallioppimisella hän tarkoittaa jonkin työvaiheen näyttämistä nuorelle "kädestä pitäen" nuoren toistaessa saman vaiheen itsenäisesti esimerkkiä jäljitellen. Ajatuksena on, että työskentelyn edetessä nuoret oppivat uusia tekniikoita. Tarve mallioppimiselle kumpuaa nuorten vaihtelevasta taitotasosta. Esimerkiksi kädentaitoihin 
liittyvien työvaiheiden havainnollistaminen osoittautui ryhmätoiminnassa tarpeelliseksi. Nuorten kanssa työskennellessä asiantuntijalle tarjoutuu samalla mahdollisuus kiinnittää huomiota työskentelyn turvallisuuteen ja erilaisiin tekemisen kynnystä madaltaviin tekijöihin. Ammattilaisena annetut vinkit ja neuvot voivat myöhemmin helpottaa nuorten työskentelyä kotona. Pienryhmissä tapahtuvat ohjaustilanteet loivat nuorten ja asiantuntijoiden välille vuorovaikutusta, jossa nuoret aktivoituivat ja saattoivat tuoda keskusteluun arkisia ongelmiaan yhdessä pohdittaviksi.

Asiantuntijat huomioivat myös nuorten erilaiset tarpeet eriyttämällä yhdessä tekemistä nuorten taitotason, työskentelyn sisältöjen tai ryhmätoiminnan dynamiikan kannalta. Parin kanssa työskentely on osalle nuorista vaikeaa, mutta taitava ohjaaja suunnittelee työskentelyn siten, että nuorille järjestyy omaa tilaa sekä mahdollisuuksia vuorovaikutukseen. Helena kertoo eriyttävänsä opetusta työpistetyöskentelyn avulla nuorten vuorovaikutuksen edistämiseksi.

Hän (toimintaan osallistuva nuori) ei varmaan itse tajunnutkaan mut aina välillä hänen vieressään kävi joku toinen pilkkomassa raaka-aineita. Eli näitä ujutuksiahan tapahtuu mutta nuori ei sitä tiedä. Siedätystä, et hei tässä on hyvä tila et tuu sä tähän pilkkomaan. (Haastattelu 9, Helena.)

Asiantuntijat kertovat käyttävänsä tilannekohtaista harkintakykyä (myös Hovi-Pulsa 2011, 96). Toisin sanoen nuoren työskentelytapoihin puuttumista pohditaan huolellisesti; usein yhteiseen tekemiseen osallistuminen asetetaan teknisten työvaiheiden suorittamista tärkeämpään asemaan. Asiantuntijat asettavat työskentelyssä etusijalle sujuvasti etenevän ryhmäkerran, jossa nuoret saavat taitotasonsa mukaisia tehtäviä ja onnistumisen elämyksiä.

Se mitä mä yritän kuitenkin saada heille, niitä positiivisia kokemuksia ennen kaikkeen. Ja sitten just et sekin että, jos koetaan että vaikka se yhdessä syöminen on mukavaa, niin mun mielest se on aika iso asia. Silloinkin on päästy jo aika pitkälle. Et semmoinen, siellä ollaan hyvällä mielellä ja innoissaan suunnitellaan seuraavaa kertaa, mitä tehtäisiin, niin se on oikeastaan aika hyvä. (Haastattelu 6, Elli.)

Elli toivoo nuorten saavan ryhmäkerran tapahtumista positiivisia kokemuksia, jotka kantaisivat omaan arkeen. Näin nuoret kykenisivät saa- 
vuttamaan valmiuksia ja taitoja, joita arjessa toimiminen vaatii (Hämäläinen 2003, 70; Semi 2006, 118-119).

\section{Kotitalouspainotteiset materiaalit ja sisällöt osaamisen vahvistamisessa}

Yleisten pedagogisten ratkaisujen lisäksi ryhmätoiminnassa korostui sisältöjen ja työskentelyssä käytettävien materiaalien kotitalouspainotteisuus. Työskentelyssä hyödynnettiin monipuolisesti ruokaan ja ravitsemukseen, kodin puhtaanapitoon ja vaatehuoltoon sekä kuluttajuuteen liittyviä materiaalisia työvälineitä, kuten tuotenäytteitä, ohjevihkoja, pelejä, tehtäviä tai kuvia. Erilaiset materiaalit toimivat virikkeinä päivän teemaan sekä myös tukena vuorovaikutuksen käynnistämisessä. Työskentelyssä käytetään myös järjestön tuottamaa neuvontamateriaalia paperiversiona ja sähköisessä muodossa. Ensimmäisellä ryhmäkerralla nuorille jaetaan Kotiruokaa kolikolla -opas, jota hyödynnetään seuraavilla kerroilla edullisten ja monipuolisten ateriakokonaisuuksien suunnittelussa ja valmistamisessa. Työskentelyn jälkeen opas jää nuoren käyttöön. Asiantuntijoilla on myös itselleen kokoamat, eri teemoihin liittyvät materiaalipankit työskentelyn tukena. Sirkka kuvaa materiaalipankkiaan "marttapakkana", jonka hän on fyysisesti kuljettanut mukanaan ryhmäkerralle tukemaan päivän teeman läpikäymistä. "Marttapakan" sisältö vaihtelee siis ryhmäkerran aiheiden mukaan.

Ja, sitten minä vedän sieltä mun "marttapakan" esille, oli kyseessä mikä tahansa aihe niin siinä alussa yleensä, käydään teoriaa. Ja välillä se on sitä, nii ku ihan oikeesti mä esittelen siellä erilaisia pesuaineita tai tälläistä. (Haastattelu 1, Sirkka.)

Puhtaanapidon opetuksessa Sirkan "marttapakkaan" kuuluu esimerkiksi erilaisia pesuaineita, joita kokeillaan eri työpisteillä ruoanvalmistuksen rinnalla. "Marttapakka" sisältää myös "siivouskalenterin", jonka avulla nuorten välille herätellään keskustelua kodin siivoustarpeista ajatuksena sijoittaa kalenteriin päivittäin, viikoittain tai kuukausittain toistuvia kodin puhtaanapidon tehtäviä. Talouden suunnittelua ja arkimenojen seuraamista voidaan puolestaan havainnollistaa heräteostosten avulla: asiantuntijat ovat koonneet esimerkkiostoksia, joihin kauppareissulla kuluu huomaamatta rahaa (mm. makeiset, sipsit, olut). Ryhmätoiminnan materiaaleissa ja toteutuksessa tulee esille asiantuntijoiden omia painotuk- 
sia. Helena pitää nuorten talousosaamista tärkeänä ja ottaa aiheen esille heti työskentelyn alkuvaiheessa hyödyntämällä esimerkiksi Takuusäätiön ja Marttaliiton tuottamaa Rahat riittää! -aineistoa. Työskentelyn aikana asiantuntijat ohjaavat nuoria pohtimaan, paljonko rahaa on käytettävissä kuukaudessa ja mihin se kuluu.

Mun sydäntä lähellä on tuo talousneuvonta. Koska se raha näyttelee niin paljon myös tässä kun puhutaan ruokavalinnoista. Otan sen siihen jo heti mukaan, ja sit tavallaan mä muistuttelen, että hei oottekste seurannu omaa rahan käyttöä ja miten sitä on huomioitu. (Haastattelu 9, Helena.)

Omaan talouteen liittyvät asiat läpileikkaavat lähes kaikki arjen toiminnot ja talouden hallintaan palataan erityisesti ruoan ja asumisen yhteydessä. Kotitalouspainotteisuus työskentelyn sisällöissä ilmenee ruoan käyttämisenä pedagogisena välineenä (Palojoki 2015, 2). Ryhmätoiminnassa ruoka ja raaka-aineet esitellään nuorille. Ruoanvalmistukseen orientoitumisen rinnalla raaka-aineiden esittely mahdollistaa laajemman ruokaosaamisen opetuksen. Keskustelunaiheina ovat esimerkiksi kilohintojen vertailu, edullisten tuotemerkkien valinta, satokausiajattelu, hyvinvointi, ekologisuus tai kierrättäminen. Saara kertoo, miten hän kehottaa nuoria pohtimaan ruokahävikkiä ja taloudellista ajattelua kotona tapahtuvan ruoanvalmistuksen yhteydessä.

Ruokahävikki on hyvin tärkee, mä aina korostan sitä että samaa ruokaa voi syödä useamman päivän, ja sitte jos on pakastin, harvallahan on, vuokrakämpissä on vaan jääkaappi ja pakastelokero, niin voi tehdä sitä ruokaa isomman satsin ja pakastaa osan. (Haastattelu 4, Saara.)

Konkreettisena ratkaisuna niin hävikin vähentämiseen kuin rahan säästämiseen Saara ohjeistaa valmistamaan ruokaa kerralla suuremman määrän. Ryhmätoiminnan yhteydessä nuori saa ohjeita siihen, miten hävikkiä voidaan välttää tai millaiset ruokalajit sopivat lämmitettäviksi tai pakastettaviksi. Ryhmästä riippuen tähän aiheeseen liittyviä keskusteluja on mahdollista laajentaa eri suuntiin (esimerkiksi ilmastonmuutokseen) nuorten kiinnostuksen mukaan.

Ruokaan liittyvien sisältöjen suhteen työskentelyssä edetään nuorten arki edellä eli huomioidaan nuorten ruoanvalmistuskokemus sisältöjen suunnittelussa ja toteutuksessa. Esimerkiksi ruoan valmistaminen alusta 
saakka ei tule kysymykseen kaikkien nuorten kohdalla. Jos nuori ei ole aiemmin valmistanut ruokaa, on asiantuntijan keksittävä ratkaisu siihen, miten työskentely saadaan käyntiin. Puolivalmisteiden hyödyntäminen voi olla ensimmäinen askel kotona syömiseen ja haluun ryhtyä kehittämään omia ruokakäytäntöjä. Helena kertoo ehdottavansa nuorille vaihtoehtoja raaka-aineiden korvaamiseen ruoanvalmistuksen helpottamiseksi ja nopeuttamiseksi. Hänen työskentelystään välittyy myönteinen asenne puolivalmisteiden käyttöä kohtaan.

On myös olemassa onneksi sipulijauheet, joita on sallittua käyttää. Mutta, eli se oivallus myös heille että ruokaa voi tehdä myös puolivalmisteesta. Eli olen ihan surutta tätä opettanut, koska kohderyhmä on ollut haasteellinen. (Haastattelu 9, Helena.)

Myös nuorten taitotaso huomioidaan: jos sipulin pilkkominen on liian haastavaa nuorille, sitä ei oteta työskentelyyn. Pienetkin asiat voivat tuntua haastavilta toteuttaa kotona ja siten estää tekemistä. Asiantuntijat pyrkivät löytämään nuorille vaihtoehtoisia polkuja esteiden ylittämiseen. Ruoanvalmistuksessa korostuu helppous ja vaivattomuus. Asiantuntijoiden näkemyksen mukaan nuorten arkeen kiinnittyvät parhaiten helpot, nopeat ja edulliset ruokalajit, kuten porkkanarieska ja tuorepuurot.

Ryhmätoimintaan kietoutuu tulevaisuusorientaatio sekä pyrkimys kiinnittää nuoren arjen sujuvuutta lisääviä toimintoja hyvinvoinnin parantamiseksi. Siirtymävaiheiden tukemista ja nuorten kanssa työskentelyä voi kuvata silloittamiseksi (Engeström, Kerosuo \& Kajamaa 2007, 323), jossa pyritään edistämään nuorten oppimispolun jatkumista ryhmätoiminnan jälkeen. Ruoanvalmistukseen liittyvän ryhmätoiminnan yhteydessä pyritään löytämään nuorten arkea helpottavia toimintatapoja. Nuorille jaettavien materiaalien ja erilaisiin sovelluksiin tutustumisen tehtävä on auttaa taitojen kehittämisessä myöhemminkin. Asiantuntijat kokevat, että käytännön harjoittelun ohessa taitojen ja toimintojen merkityksellistäminen nuoren kokemusmaailmaan on tärkeää.

Vaikka asiantuntijat kartoittivat nuorten elämismaailmaa, taitoja ja avun tarvetta sekä sovelsivat erilaisia pedagogisia metodeja nuorten tukemisessa, haastatteluista välittyi myös kotitalouden ammattiosaamisen sisältöjen ja toimintatapojen jännitteisyys. Suomalaisessa yhteiskunnassa - ja kotitalousopetuksessa - on arvostettu itsetekemisen eetosta (Heinonen 1998). Tämä ajattelutapa tuottaa jännitteen "isompien ruokasatsien ja 
pakastamisen" sekä puolivalmisteiden käytön välillä. Myös nuorten osaamattomuuden ymmärtämisessä kotitalouden professio, jossa aktiivisuus ja taitojen oppiminen on tärkeää, estää osin näkemästä nuorten tilanteen haavoittuvuutta. Neuvojien tilannetaju sekä kyky räätälöidä ja improvisoida erilaisia ratkaisuja haastaviin tilanteisiin ilmentää kuitenkin neuvontatyön sopeuttamista nuorten elämäntilanteeseen.

\section{Johtopäätökset}

Olemme tarkastelleet kotitalousasiantuntijoiden näkemyksiä nuorille suunnatusta arjen sujuvuutta ja osaamista vahvistavasta neuvontatyöstä. Neuvontatyötä on toteutettu ryhmätoiminnan menetelmin ja sen tavoitteena on nuorten siirtymävaiheiden tukeminen. Tarkastelimme sitä, miten kotitalousasiantuntijat rakentavat yhteistä tulkintahorisonttia (Hovi-Pulsa 2011, 87) nuorten kanssa neuvonta- ja ohjaustyön yhteistoteutuksesta sekä mitä pedagogisia ratkaisuja ja työskentelyn sisältöjä asiantuntijat kertovat käyttävänsä nuorten tukemisessa ja ohjaamisessa. Haavoittuvassa asemassa olevat nuoret ovat haastava ryhmä perinteisille kotitalousneuvonnan käytänteille (mm. Ollila 1993; Heinonen 1998; Jalovaara 2019). Tässä yhteydessä arkilähtöinen työote painottuu enemmän nuorten ohjaamiseen (15-29-vuotiaat) ja toiminnan aktivointiin kuin neuvontaan, jossa toiminnan kohteena on tavallisesti vertainen. Asiantuntijat yhtäältä sopeuttavat omaa työskentelyään nuorten elämismaailmaan (mm. aikarytmiin) sekä toisaalta tukevat yhdessä tekemistä ja oppimista erilaisten pedagogisten menetelmien, kuten mallioppimisen ja vertaisoppimisen sekä kotitalouspedagogisten ratkaisujen, kuten ruoan, vaatehuollon ja kuluttamisen sekä niitä tukevien materiaalien ( $\mathrm{mm}$. ohjevihkojen, pelien, tuotenäytteiden, videoiden) avulla. Näin työskentely ohjaa asiantuntijoita toimimaan painotetummin kasvattajina, ja toimintaa voisi kuvata arkilähtöiseksi kotitalouskasvatukseksi (vrt. Kauppinen 2018), joka tapahtuu koulutusinstituution ulkopuolella (vrt. koulun kotitalousopetus).

Nuorten ohjaustyön kohdentaminen käynnistyy, kun työntekijät kartoittavat nuorten taitotason sekä heidän suhtautumistaan ryhmätoimintaan ja sen sisältöihin. Mallioppiminen käynnistää käytännön työskentelyn, kun asiantuntijat konkreettisesti näyttävät eri työvaiheita nuorille. Vastaavasti vertaisoppiminen koetaan toimivana, koska samankaltaisissa tilanteissa elävien nuorten arjesta löytyi yhtymäkohtia ja niihin voitiin yhdessä tarttua ryhmätyöskentelyn aikana (Topping 2005). Erityisen toimivaa vertaisoppiminen oli, kun työtavat räätälöitiin nuorten arjen koke- 
musmaailmaan (Grunwald \& Thiersch 2009), jolloin harjoittelun kohteena olevilla toimintatavoilla oli jo tarttumapintaa nuorten aikaisempiin kokemuksiin. Tutkimus osoittaa, että neuvontatyön sisältöjä ja menetelmiä kehittämällä nuorelle voidaan tarjota konkreettisia välineitä arjen käytäntöjen muuttamiseen, kehittämiseen ja sujuvoittamiseen (Hämäläinen 2003, 70) sekä tukea välillisesti nuoren kasvua ja oman paikan löytämistä yhteiskunnassa erityisesti ryhmätoiminnan keinoin (Nivala 2007, 30). Tutkimus herättää kuitenkin laajemmin kysymyksen työskentelyn pedagogisista ratkaisuista ja sisällöistä suhteessa nuoren omaan toimintaympäristöön, koska perimmäisenä ajatuksena on uusien toimintojen kiinnittyminen nuoren arkeen. Ryhmätoiminnassa toimivilta tuntuvat ratkaisut ja sisällöt eivät välttämättä kiinnity osaksi arjen toimintoja nuoren omassa elämässä. Ratkaisuna voisi olla neuvontatyön vieminen nuoren omaan kotiin (Hämäläinen 2003) eli sosiaalipedagogisen työotteen vahvistaminen. Näin arjen todellisuuden tavoittaminen olisi konkreettisempaa ja neuvonta kohdistuisi arjessa esille tulleisiin haasteisiin.

Arjen taitoja opetellaan yhä enemmän kodin ja koulun ulkopuolella, erilaisissa oppimisen konteksteissa, esimerkiksi osana kolmannen sektorin työskentelyä. Monipuolisemmille oppimisympäristöille on tarvetta, koska arjessa tarvittavat tiedot ja taidot eivät välttämättä siirry kodeissa seuraaville sukupolville (esim. Knight, O’Connell \& Brannen 2014). Tutkimus rakentaa ymmärrystä siitä, miten arkilähtöinen kotitalousneuvonta tuo käytännöntaitojen opettamisen osaksi nuorten siirtymävaiheen tukemista.

Tutkimus nostaa esiin, millaisia oppimisen ja ohjaamisen keinoja kotitalousneuvonnalla on tarjota nuorille etsittäessä uusia ja vaihtoehtoisia polkuja (vrt. Hiilamo ym. 2017), joita haavoittuvassa elämäntilanteessa olevat nuoret tarvitsevat perinteisten aktivointitoimenpiteiden rinnalle. Ei riitä, että tuetaan vain nuorten koulutus- ja työelämäpolkuja, vaan nuoret tarvitsevat tukea myös arjessa toimimiseen. Itsenäistä arkea rakentavan nuoren on myös opittava vastuunottoa itsestään, kotitaloustöistä ja raha-asioista (Allen \& Williams 2012; Korvela \& Nordlund 2016) työ- ja koulutusosaamisen rinnalla. Tätä osaamista on mahdollista tukea kotitalousneuvontatyön kautta, jossa lisätään nuoren ymmärrystä omista toimintamahdollisuuksistaan (ks. myös Hämäläinen 2012, 12; Ranne 2007). Hanketyöskentelyyn osallistuminen mahdollistaa kodista pois lähtemisen, aktivoitumisen (vrt. Nivala \& Ryynänen 2007), vaikka se olisikin nuorelle 
pakotettua toimintaa. Olisikin tärkeä tutkia nuorten omia kokemuksia ja tulkintoja kotitalousneuvonnasta. Nuoria tuetaan entistä enemmän arjen taidoissa (ks. Välimäki ym. 2020, 25). Uusien ammattiryhmien osallistuminen nuorten tukemiseen muuttaa vallitsevaa ajattelutapaa. Myös arjen taidot ovat tärkeä osa elämässä "pärjäämistä".

Tutkimus osoittaa, että nuoren elämismaailman tavoittaminen käytännön työskentelyn yhteydessä ei aina ole ongelmatonta. Osaamisen edistäminen voi kapeutua päivän teemaan ryhmätoiminnassa (kodin puhtaanapitoon, ruokahuoltoon), ellei asiantuntija saa rakennettua vuorovaikutusyhteyttä nuoren kanssa. Myös kotitalousammattilaisen asema ohjaa helposti neuvontatyön tekijää tulkitsemaan nuoren tuen tarpeen "vain" arjen sujuvuuden tai profession näkökulmasta, eikä välttämättä nuoren itsensä kokemien ongelmien kautta (Hovi-Pulsa 2011). Myös herkkyys pohtia neuvontatyön sisältöjä yhdessä nuorten kanssa voisi avata yhteistä tulkintahorisonttia, johon arkilähtöisyys pohjaa (Grunwald \& Thiersch 2009). Vaikka kotitalouden profession käytäntölähtöisyys voi yhtäältä lieventää muihin tukimuotoihin liittyviä jännitteitä, kun nuori innostuu käytännön tekemisestä, liittyy siihen kuitenkin vahvoja oletuksia nuoren aktiivisuudesta, mikä voi puolestaan tuottaa (tahattomasti) passiivisuutta - ja jopa lisätä haavoittuvuutta (Virokannas ym. 2020).

Nuorten tuen tarve on tämänhetkisiä nuorten työllistymisen edistämiseen liittyviä tavoitteita laajempi ja moninaisempi (vrt. Komonen 2008; Hiilamo ym. 2017). Nuoret tarvitsevat tukea ja taitoja omasta hyvinvoinnistaan huolehtimiseen. Hyvinvoinnin edistäminen kehittää myös valmiuksia opinnoissa ja työelämässä selviämiseen. On tärkeää, että nuoret voivat toimia yhteiskunnassa itselleen tärkeiden asioiden parissa ja saada toiminnalleen tukea (Nivala \& Ryynänen 2019, 246). Arkeen kohdistuva tuki ei kuitenkaan yksin riitä haavoittuvissa elämäntilanteissa eläville nuorille, vaan heidän tukemisensa vaatii moniammatillista yhteistyötä. Lyhytkestoinen hanketyöskentely asettaa omat reunaehtonsa nuorten arjen ja oppimispolkujen silloittamiseksi eteenpäin. Hovi-Pulsan (2011) kuvaama arkilähtöinen työskentely on intensiivistä ja pitkäkestoista asiakkaan vierellä kulkemista (Thiersch 1986), mikä ei ole mahdollista hanketyöskentelyn resursseilla. 


\section{LÄHTEET}

Aaltonen, S. \& Kivijärvi, A. 2017. Hyvinvointipalvelut ja nuoret aikuiset - Ohjausta monimutkaistuneissa siirtymissä. Teoksessa S. Aaltonen \& A. Kivijärvi (toim.) Nuoret aikuiset hyvinvointipalvelujen käyttäjinä ja kohteina. Verkkojulkaisuja 136. Helsinki: Nuorisotutkimusverkosto/Nuorisotutkimusseura, 7-24. Saatavissa https://www. nuorisotutkimusseura.fi/images/nuoret_aikuiset_hyvinvointipalvelujen_kayttajina_ ja_kohteina_lopullinen.pdf (haettu 6.6.2020).

Aaltonen, S., Berg, P. \& Ikäheimo, S. 2015. Nuoret luukulla. Kolme näkökulmaa syrjäytymiseen ja nuorten asemaan palvelujärjestelmässä. Julkaisuja 160. Helsinki: Nuorisotutkimusverkosto/Nuorisotutkimusseura.

Aineistonhallinnan käsikirja 2019. Tampere: Yhteiskunnallinen tietoarkisto. Saatavissa http://www.fsd.uta.fi/aineistonhallinta/fi/tunnisteellisuus-ja-anonymisointi.html (haettu 21.2.2020).

Allen, T. T. \& Williams, L. D. 2012. An approach to Life Skills Group Work With Youth in Transition to Independent Living: Theoretical, Practice, and Operational Consideration. Residential Treatment for Children \& Youth 29 (4), 324-324. DOI: 10.1080/0886571X.2012.725375.

Arnardottir, J. R. 2020. Transition from School to Work: Icelandic Young People in NEET. Teoksessa K. Brunila \& L. Lundahl (eds.) Youth on the Move: Tendencies and Tensions in Youth Policies and Practices. Helsinki: Helsinki University Press, 57-77. DOI: https://doi.org/10.33134/HUP-3-4.

Autio, M., Lähteenmaa, J., Holmberg, U. \& Kujala, J. 2016. Young consumer identity in a restrictive school environment - Addictive substances, symbolic goods and consumer skills. Children and Youth Services Review 68, 100-106. DOI: https://doi. org/10.1016/j.childyouth.2016.07.003.

Campbell, C. A. \& Brigman, G. 2005. Closing the achievement gap: A structured approach to group counseling. The Journal for Specialists in Group Work 30 (1), 67-82. DOI: https://doi.org/10.1080/01933920590908705.

Edwards, A. \& Hedegaard, M. 2019. Rethinking Professional Support for Challenging Transitions: Enabling the Agency of Children, Young People and Their Families. Teoksessa M. Hedegaard \& A. Edwards (eds.) Supporting Difficult Transitions. Children, Young People and their Carers. London: Bloomsbury Academic, 1-18.

Engeström, Y., Kerosuo, H. \& Kajamaa, A. 2007. Beyond Discontinuity: Expansive Organizational Learning Remembered. Management Learning 38 (3), 319-336. DOI: https://doi.org/10.1177\%2F1350507607079032.

Fabian, H. \& Dunlop, A-W. 2002. Introduction. Teoksessa H. Fabian \& A-W. Dunlop (eds.) Transitions in the early years. Debating continuity and progression for young children in early education. London: Routledge, 1-7.

Featherstone, M. 1992. The Heroic Life and Everyday Life. Theory, Culture \& Society 9 (1), 159-182. DOI: https://doi.org/10.1177/026327692009001009.

Felski, R. 1999. The Invention of Everyday Life. New Formations 39, 13-31. 
Fontana, A. \& Frey, J. H. 2003. The Interview: From Structured Questions to Negotiated Text. Teoksessa N. K. Denzin \& Y. S. Lincoln (eds.) Collecting and Interpreting Qualitative Materials. 2nd edition. Thousand Oaks: Sage Publications, 61-106.

Gale, T. \& Parker, S. 2014. Navigating change: a typology of student transition in higher education. Studies in Higher Education 39 (5), 734-753. DOI: https://doi.org/10.108 0/03075079.2012.721351.

Grunwald, K. \& Thiersch, H. 2009. The concept of the 'lifeworld orientation' for social work and social care. Journal of Social Work Practice 23 (2), 131-146. DOI: 10.1080/02650530902923643.

Hedegaard, M. \& Fleer, M. 2019. Children's Transitions in Everyday Life and Institutions. London: Bloomsbury Academic.

Heinonen, V. 1998. Talonpoikainen etiikka ja kulutuksen henki. Kotitalousneuvonnasta kuluttajapolitiikkaan 1900-luvun Suomessa. Helsinki: Suomen Historiallinen Seura.

Heinonen, V. 2012. Arkielämän tutkimusperinteet, kulutus ja rutiinit. Kulutustutkimus. Nyt 6 (1), 60-74.

Hiilamo, H., Komp, K., Moisio, P., Babila, S. T., Lauronen, J., Karimo, A., Mäntyneva, P., Parpo, A. \& Aaltonen, H. 2017. Neljä osallistavan sosiaaliturvan mallia. Valtioneuvoston selvitys- ja tutkimustoiminnan julkaisusarja: 18/2017. Helsinki: Valtioneuvoston kanslia. Saatavissa http://julkaisut.valtioneuvosto.fi/handle/10024/160216 (haettu 4.2.2020).

Hiilamo, H. 2018. Osallistumistulo kannustaisi nuoria opiskeluun. Aikuiskasvatus 38 (2), 148-155. Saatavissa https://journal.fi/aikuiskasvatus/article/download/88336/47503 (haettu 19.2.2020).

Honkatukia, P. 2018. Haastattelu nuorisotutkimuksen metodina. Teoksessa T. Kiilakoski \& P. Honkatukia (toim.) Miten tutkia nuoria ja nuorisotyötä. Tampere: Vastapaino, 149-170.

Hovi-Pulsa, R. 2011. Arkilähtöinen perhetyö. Strukturoitua avoimuutta. Lisensiaattityö. Kuopio: Itä-Suomen yliopisto, Yhteiskuntatieteiden laitos. Saatavissa https:// epublications.uef.fi/pub/urn_nbn_fi_uef-20120001/urn_nbn_fi_uef-20120001.pdf (haettu 3.6.2020).

Hsieh, H. F. \& Shannon, S. E. 2005. Three Approaches to Qualitative Content Analysis. Qualitative Health Research 15 (9), 1277-1288.

Hyvönen, U. \& Valtonen, M. 2014. Nuorisotakuu - ehjä kokonaisuus vai kasa toimenpiteitä? Teoksessa A. Gretschel, K. Paakkunainen, A-M. Souto \& L. Suurpää (toim.) Nuorisotakuun arki ja politiikka. Verkkojulkaisuja 76. Helsinki: Nuorisotutkimusverkosto/Nuorisotutkimusseura, 33-37. Saatavissa http://www. nuorisotutkimusseura.fi/images/julkaisuja/nuorisotakuun_arki_ja_politiikka.pdf (haettu 14.2.2020).

Häggman-Laitila, A., Salokekkilä, P. \& Karki, S. 2018. Transition to adult life of young people leaving foster care: A qualitative systematic review. Children and Youth Service Review 95, 134-143. DOI: https://doi.org/10.1016/j.childyouth.2018.08.017.

Hämäläinen, J. 2003. Arkilähtöinen sosiaalipedagogiikka. Sosiaalipedagoginen aikakauskirja 4, 65-75. 
Hämäläinen, J. 2012. Social pedagogical eyes in the midst of diverse understandings, conceptualisations and activities. International Journal of Social Pedagogy 1 (1), 3-16. DOI: https://doi.org/10.14324/111.444.ijsp.2012.v1.1.002.

Jalovaara, V. 2019. On suurempi koti. Martat 120 vuotta. Helsinki: Kustannusosakeyhtiö Otava.

Juvonen, T. 2015. Sosiaalisesti kontrolloitu, hauraasti autonominen: Nuorten toimijuuden rakentuminen etsivässä työssä. Julkaisuja 165. Helsinki: Nuorisotutkimusverkosto/ Nuorisotutkimusseura. Saatavissa https://www.nuorisotutkimusseura.fi/images/ kuvat/verkkojulkaisut/sosiaalisesti_kontrolloitu.pdf (haettu 3.6.2020).

Karjalainen, J. \&Viljanen, O. 2009. Arki kuntoon - lainrikkojien tuen tarve. Avauksia 14/2009. Helsinki: THL. Saatavissa https://www.julkari.fi/bitstream/handle/10024/79864/ f184822f-8e87-42d5-97af-537af161af63.pdf?sequence=1 (haettu 17.6.2020).

Kauppinen E. 2018. Moniääninen ruokaympäristö. Ruokakasvatuksen mahdollisuudet nuorisotaloilla. Kasvatustieteellisiä tutkimuksia 38. Helsinki: Helsingin yliopisto. Saatavissa https://helda.helsinki.fi/bitstream/handle/10138/251189/MONIAANI. pdf? sequence $=1$ \&isAllowed $=y$ (haettu 15.6.2020).

Kausholt, D. 2019. Children's Everyday Transitions: Children's Engagements across Life Contexts. Teoksessa M. Hedegaard \& M. Fleer (eds.) Children's Transitions in Everyday Life and Institutions. London: Bloomsbury Academic, 145-166.

Kestilä, L., Kauppinen, T. M. \& Karvonen, S. 2016. Lapsuuden elinolojen yhteys arjenhallintaan nuorilla aikuisilla. Teoksessa S. Myllyniemi (toim.) Arjen jäljillä. Nuorisobarometri 2015. Verkkojulkaisuja 93. Helsinki: Opetus- ja kulttuuriministeriö, Nuorisoasiain neuvottelukunta, Nuorisotutkimusseura, 117-134. Saatavissa https:// tietoanuorista.fi/wp-content/uploads/2016/01/Nuorisobarometri_2015_ISSUU.pdf (haettu 5.2.2020).

Kiilakoski, T. 2014. Kahdenlaisia ja kolmenlaisia ihmisiä. Teoksessa A. Gretschel, K. Paakkunainen, A-M. Souto \& L. Suurpää (toim.) Nuorisotakuun arki ja politiikka. Verkkojulkaisuja 76. Helsinki: Nuorisotutkimusverkosto/Nuorisotutkimusseura, 2427. Saatavissa http://www.nuorisotutkimusseura.fi/images/julkaisuja/nuorisotakuun_ arki_ja_politiikka.pdf (haettu 11.2.2020).

Knight, A., O’Connell, R. \& Brannen, J. 2014. The temporality of food practices: intergenerational relations, childhood memories and mothers' food practices in working families with young children. Families, Relationships and Societies 3 (2), 303-318.

Kojo, M. 2012. Pause päällä. Työn ja koulutuksen ulkopuoliset jaksot nuorten elämänkulussa. Janus - Sosiaalipolitiikan ja sosiaalityön tutkimuksen aikakauslehti 20 (2), 94-110.

Komonen, K. 2008. Nuorten työpajat kasvatuksellisina instituutioina. Janus Sosiaalipolitiikan ja sosiaalityön tutkimuksen aikakauslehti 16 (2), 167-174. Saatavissa https://journal.fi/janus/article/download/50467/15260 (haettu 11.2.2020).

Kortesalmi, M. \& Autio, M. 2019. Talous- ja kuluttajakasvatus talousosaamisen mahdollistajana. Kansantaloudellinen aikakauskirja 115 (4), 588-603. Saatavissa https://www.taloustieteellinenyhdistys.fi/wp-content/uploads/2019/11/

KAK_4_2019_WEB-10-25.pdf (haettu 26.9.2020). 
Korvela, P. \& Nordlund, A. 2016. Nuorten arjen rytmit ja perhe. Teoksessa S. Myllyniemi (toim.) Arjen jäljillä. Nuorisobarometri 2015. Verkkojulkaisuja 93. Helsinki: Opetusja kulttuuriministeriö, Nuorisoasiain neuvottelukunta, Nuorisotutkimusseura, 193-205. Saatavissa https://tietoanuorista.fi/wp-content/uploads/2016/01/ Nuorisobarometri_2015_ISSUU.pdf (haettu 5.6.2020).

Korvela, P. 2014. Arjen rakentumisen ja rytmien kokoavaa tarkastelua. Teoksessa P. Korvela \& T. Tuomi-Gröhn (toim.) Arjen rakentuminen ja rytmit perhe-elämän käännekohdissa. Helsinki: Kuluttajatutkimuskeskus, 318-339. Saatavissa https://helda. helsinki.fi/bitstream/handle/10138/153029/14\%20Korvela.pdf (haettu 4.6.2020).

Lefebvre, H. 2002. Everyday Life in the Modern World. Kääntäjä S. Rabinovitch. Alkuperäisteos 1971. New Brunswick and London: Transaction Publishers.

Liabo, K., McKenna, C., Ingold, A. \& Roberts, H. 2016. Leaving foster or residential care: a participatory study of care leavers' experiences of health and social care transitions. Child: Care, Health \& Development 43 (2), 182-191. DOI: https://doi.org/10.1111/cch.12426.

Mary, A. 2012. The Illusion of the Prolongation of Youth - Transition to Adulthood among Finnish and French Female University Students. Tampere: Tampere University Press.

Melandro, R., Campos, G., Rodriguez-Bravo, A. E. \& Arroy Resino, D. 2020. Young People's Autonomy and Psychological Well-Being in the Transition to Adulthood: A Pathway Analysis. Frontiers in Psychology 11 (article 1946). DOI: https://doi. org/10.3389/fpsyg.2020.01946.

Muukkonen, T., Nevalainen, S., Ohisalo, M. \& Turunen, S. 2014. Yksikin aikuinen riittää: nuoren sosiaalinen vahvistaminen ja voimaantuminen Luotsi-toiminnassa. Nuorisotutkimus 32 (3), 17-32. Saatavissa https://elektra.helsinki.fi/oa/07800886/2014/3/yksikina.pdf (haettu 16.6.2020).

Nivala, E. \& Ryynänen, S. 2017. Sosiaalipedagoginen viitekehys nuorisoalan työssä. Teoksessa T.Hoikkala \&J.Kuivakangas (toim.) Kenen nuorisotyö? Yhteisöpedagogiikan kentät ja mahdollisuudet. Helsinki: Humanistinen ammattikorkeakoulu, Nuorisotutkimusseura/Nuorisotutkimusverkosto, 75-92. Saatavissa https://www. humak.fi/wp-content/uploads/2017/12/hoikkala-kuivakangas-kenen-nuorisotyo.pdf (haettu 4.6.2020).

Nivala, E. \& Ryynänen, S. 2019. Sosiaalipedagogiikka - Kohti inhimillisempää yhteiskuntaa. Helsinki: Gaudeamus.

Nivala, E. 2007. Sosiaalipedagogiikka nuorten yhteiskunnallisen kasvun tukena. Sosiaalipedagoginen aikakauskirja 8, 7-96.

Ollila, A. 1993. Suomen kotien päivä valkenee... Marttajärjestö suomalaisessa yhteiskunnassa vuoteen 1939. Historiallisia tutkimuksia 173. Helsinki: Suomen historiallinen seura.

Palojoki, P. 2015. Johdanto. Teoksessa H. Janhonen-Abruquah \& P. Palojoki (toim.) Luova ja vastuullinen kotitalousopetus. Kotitalous- ja käsityötieteiden julkaisuja 38. Helsinki: Helsingin yliopisto, 1-5.

Paulsen, V. \& Berg, B. 2016. Social support and interdependency in transition to adulthood from child welfare services. Children and Youth Services Review 68, 125131. DOI: https://doi.org/10.1016/j.childyouth.2016.07.006. 
Pekkarinen, E. 2015. Arjen ja elämänhallinnan ongelmat lapsuudenperheessä - lastensuojelun näkökulma. Teoksessa S. Myllyniemi (toim.) Arjen jäljillä. Nuorisobarometri 2015. Verkkojulkaisuja 93. Helsinki: Opetus- ja kulttuuriministeriö, Nuorisoasiain neuvottelukunta, Nuorisotutkimusseura, 163-180. Saatavissa https:// tietoanuorista.fi/wp-content/uploads/2016/01/Nuorisobarometri_2015_ISSUU.pdf (haettu 5.2.2020).

Ranne, K. 2007. Sosiaalipedagogiikka Suomessa - Sosiaalipedagogiikka ammatillisten käytäntöjen kehittämisessä ja koulutuksessa. Aikuiskasvatus 27 (4), 304-311. Saatavissa https://journal.fi/aikuiskasvatus/article/view/93784 (haettu 4.6.2020).

Salmi, M. 2004. Arkielämä kokoaa yhteen työn ja perheen. Teoksessa M. Salmi \& J. Lammi-Tastula (toim.) Puhelin, mummo vai joustava työaika. Työn ja perheen yhteensovittamisen arkea. Helsinki: Sosiaali- ja terveysalan tutkimus- ja kehittämiskeskus, 11-28.

Salo, U-M. 2015. Simsalabim, sisällönanalyysi ja koodaamisen haasteet. Teoksessa S. Aaltonen \& R. Högback (toim.) Umpikujasta oivallukseen. Refleksiivisyys empiirisessä tutkimuksessa. Tampere: Tampere University Press, 166-190.

Sekki, S. \& Autio, M. 2020. Kotitalousneuvonta nuorten sosiaalisten suhteiden, arjen rytmien ja taitojen tukemisessa. Teoksessa T. Valkendorff \& E. Sihvonen (toim.) Nuorten perhe- ja läheissuhteet. Nuorten elinolot -vuosikirja 2020. Helsinki: Nuorisotutkimusverkosto/Nuorisotutkimusseura, Terveyden ja hyvinvoinnin laitos, Valtion nuorisoneuvosto, 201-217.

Semi, E. 2006. Sosiaalialan ja sosiaalipedagogiikan yhteys ammattikorkeakoulujen sosiaalialan koulutusohjelmissa. Diakonia-ammattikorkeakoulun julkaisuja A. Tutkimuksia 13. Helsinki: Diakonia-ammattikorkeakoulu. Saatavissa https://www. theseus.fi/bitstream/handle/10024/142084/A_13_web.pdf?sequence=1 (haettu 15.6.2020).

Thiersch, H. 1986. Die Erfahrung der Wirklichkeit. Weinheim/ München: Juventa.

Topping, K. J. 2005. Trends in peer learning. Educational Psychology 25 (6), 631-645. DOI: https://doi.org/10.1080/01443410500345172.

Tuomi, J. \& Sarajärvi, A. 2009. Laadullinen tutkimus ja sisällönanalyysi. Helsinki: Tammi.

Virokannas, E., Liuski, S. \& Kuronen, M. 2020. The contested concept of vulnerability - a literature review. European Journal of Social Work 23 (2), 327-339. DOI: https://doi. org/10.1080/13691457.2018.1508001.

Välimäki, V., Aaltonen, S. \& Kivijärvi, A. 2020. Nuorten palvelut yksinäisyyden lievittäjinä? Kohdennetun nuorisotyön piirissä olevien nuorten aikuisten ja ammattilaisten näkemysten tarkastelua. Nuorisotutkimus 38 (2), 22-36.

Westergaard, J. 2013. Counselling young people: Counsellors' perspectives on 'what works'- An exploratory study. Counselling and Psychotherapy Research 13 (2), 98105. DOI: https://doi.org/10.1080/14733145.2012.730541.

Westermarck, H. 2014. Asiantuntija muutosagenttina: neuvontaopin menestystarina Helsingin yliopistossa 1968-2015. Helsinki: Helsingin yliopisto, taloustieteen laitos. 
Woodgate, R. L., Morakinyo, O. \& Martin, K. M. 2017. Interventions for youth aging out of care: A scoping review. Children and Youth Services Review 82, 280-300. DOI: https://doi.org/10.1016/j.childyouth.2017.09.031.

Woodman, D. \& Wyn, J. 2018. How to Support Young People in a Changing World: The Sociology of Generations and Youth Work. Teoksessa P. Alldred, F. Cullen, K. Edwards \& D. Fusco (eds.) The Sage handbook of youth work practice. Los Angeles: Sage Publications, 18-29.

Xie, R., Sen, B. \& Foster, M. 2014. Vulnerable Youth and Transitions to Adulthood. New Directions for Adult and Continuing Education 2014, 29-38. DOI: https://doi. org/10.1002/ace.20102. 
38 - Sosiaalipedagoginen aikakauskirja, vuosikirja 2020, vol. 21 